\title{
The Roman Aqueduct of Aquincum in Technological and Cultural Contexts
}

\section{László Munteán}

Abstract: This article explores the technological and cultural history of the Roman aqueduct of Aquincum in Budapest. The only one in the Roman province of Pannonia that was elevated to a continuous line of arches, this aqueduct conveyed water from its source in what is now Budapest's third district to its final destination over three miles to the south, where a Roman military town was located. Apart from the aqueduct's technological and archaeological aspects, this article also examines several cultural practices that it engendered including the ritualistic significance of the springs that fed it, its appearance as a ruin in various medieval documents, the transformation of its last, above-ground pier into a Christian shrine in the nineteenth century, as well as the relocation of two of its piers to give way to the construction of a road junction.

Keywords: Aquincum, aqueduct, archaeology, Budapest, Pannonia, Roman Empire, water technology

Biography: László Munteán is an Assistant Professor with a double appointment in Cultural Studies and American Studies at Radboud University Nijmegen, the Netherlands. At the Radboud Institute for Culture and History (RICH) he leads the research group "Memory, Materiality, and Affect in the Age of Transnationalism." His publications have focused on the memorialization of 9/11 in literature and the visual arts, as well as on photography, urban culture, architecture and cultural heritage. In a broader sense, his scholarly work revolves around the juncture of literature, visual culture and cultural memory in American and Eastern European contexts. He is co-editor of Materializing Memory in Art and Popular Culture (Routledge 2017) and Animation and Memory (Palgrave 2020). laszlo.muntean@ru.nl

Although the aqueduct is not a Roman invention, the Romans perfected and systematized its construction to such a level that it became an emblem of the Empire's might and a manifestation of the ingenuity of its builders. For the Roman mind, the beauty of aqueducts lay in their functionality. As the first-century water commissioner, Julius Sextus Frontinus (ca. AD 40-103), wrote, "With such an array of indispensable structures carrying so many waters, compare, if you will, the idle Pyramids or the useless, though famous, works of the Greeks!" (Frontinus I, 16). Even as ruins, the distinct silhouettes of these monumental structures continue to remain landmarks in cities that they once supplied with water from faraway springs. The Roman province of Pannonia was located in what is now the area of Hungary west of the Danube River, including parts of Austria, Slovakia, Slovenia, Croatia, Serbia, and Bosnia and Herzegovina. The town of Aquincum was one of the most prominent settlements in the province 
Munteán, László. “The Roman Aqueduct of Aquincum in Technological and Cultural Contexts.” Hungarian Cultural Studies. e-Journal of the American Hungarian Educators Association, Volume 14 (2021) DOI:

and was located in what is now the area of Óbuda in the city of Budapest. Although less scenic than the double- and triple-tiered aqueducts of Rome and Segovia, the aqueducts of Aquincum amount to an engineering feat that amazed migrating tribes long after the fall of Rome and has intrigued archaeologists since the mid-nineteenth century.

This article explores the technological and cultural history of the Roman aqueduct of Aquincum in Budapest. The only one in the Roman province of Pannonia that was elevated to a continuous line of arches, this aqueduct conveyed water from its source in what is now the area called Rómaifürdö [literally: 'Roman baths'] in Budapest's third district to its final destination over three miles to the south, where a Roman military town was located. Apart from the aqueduct's technological and archaeological aspects, this article also examines several cultural practices that it engendered including the ritualistic significance of the springs that fed it, its appearance as a ruin in various medieval documents, the transformation of its last, above-ground pier into a Christian shrine in the nineteenth century, as well as the relocation of two of its piers to give way to the construction of a road junction.

\section{The Roman Aqueduct}

In order to set the stage for my discussion of the aqueduct of Aquincum, let us first highlight some of the salient mechanical characteristics of Roman aqueducts. Trevor Hodge's pioneering, 1992 book, Roman Aqueducts and Water Supply, was among the first to approach Roman aqueducts from an engineering, rather than an archaeological, viewpoint. An aqueduct not only provides the scenic view of arched viaducts bridging valleys and gorges, but also encompasses a complex system of underground and above-ground conduits that connected faraway springs with cities where water was distributed to serve a variety of different functions. The construction of such a network of water supplies required cutting-edge technology, engineering expertise and, last but not least, a lot of money. It is no wonder that aqueducts not only epitomized Roman pragmatism, as Frontinus boasted, but also attested to the might and prosperity of the cities that could afford them (Póczy 1980: 41; Hodge 2002: 6; Chanson 2008: 2).

Two classical sources survey the construction of aqueducts. In his seminal work, Ten Books of Architecture, Vitruvius's Book VIII provides ample instructions as to finding water and building aqueducts, wells and cisterns. The other volume is Frontinus's The Aqueducts of Rome, written as an official report on the aqueduct system of the city of Rome. While the former was primarily concerned with the theoretical and practical aspects of construction, the latter gives an insight into the social and legal issues related to the operation of the water supply (Póczy 1980: 20). Frontinus assigns the construction of the first aqueduct called Aqua Appia to the year 312 BC. This structure once ran along the famous Via Appia. During the Age of the Republic, three more were built which were soon followed by five new lines during the less than a hundred years that fell between 33 BC and AD 52 (Póczy 1980: 11). Altogether, eleven major aqueducts were built in and around the city of Rome between 312 BC and AD 226 (Ashby 1935: xi) with most of them still functioning even in the sixth century (Póczy 1980: 12). The period between the reign of Augustus (30 BC - AD 14) and Trajan (AD 98-117) was marked by the construction of myriads of aqueducts leading to the major cities of the empire (11). By AD 226, the system had reached a cumulative length of 502 kilometers (312 miles) (Chanson 2008, 5). With its length of 132 kilometers ( 82 miles), the longest system was built at Carthage, which the poet El Kairouani duly described as one of the marvels of the world (Hodge 2002: 3; Chanson 2008: 5). 
Munteán, László. “The Roman Aqueduct of Aquincum in Technological and Cultural Contexts.” Hungarian Cultural Studies. e-Journal of the American Hungarian Educators Association, Volume 14 (2021) DOI:

Surprising as it may seem, even if Frontinus refers to them as "indispensable," all the Roman settlements known for their magnificent aqueducts had already been flourishing towns before construction of a new water system commenced. This fact may dispel the popular belief that aqueducts were indispensable to supplying towns with drinking water. If drinking water was largely gained from wells, what other reasons account for the building of these costly structures then? As Hodge (2002: 5) and Chanson (2008: 2) argue, most of the aqueducts were built for public health and sanitary needs, as well as to supply water for public fountains, baths, toilets and the irrigation systems that are equally essential to a well-functioning town.

The construction of aqueducts required preliminary land surveys and careful planning. Cases of ill-designed structures that collapsed or constructions that became abandoned for lack of expertise are legion (Póczy 1980: 33). Upon conquering new territories, Roman land surveyors would divide the acquired lands into parcels of equal size to facilitate the administrative affairs related to ownership rights and taxation (26). The grid system that resulted from these divisions determined the network of roads as well as the path of conduits conveying water from faraway springs to the cities. The enormous task of designing the aqueducts was usually spearheaded by a group of engineers that included "the aquilex (hydraulics and hydrology engineer), the architectus (survey engineer, design architect) and the liberator aquae (civil and hydraulic engineer)" who collaborated on the same project (Chanson 2008: 6). Such skilled engineers were not in abundance, however. As Chanson contends,

Although there is no written proof that the engineers understood the basic concepts of continuity and energy, as used in modern hydraulics, they were contemporaries of Hero of Alexandria who understood the principle of continuity, probably those of momentum and energy. It is believed that he also influenced the Roman hydraulicians of the $1^{\text {st }}, 2^{\text {nd }}$ and $3^{\text {rd }}$ centuries $\mathrm{AD}$, and possibly the designers of the Nîmes, Mons, Montjeu and Valdepuentes aqueducts. (13)

The system was governed by the simple principle of gravity flow and the understanding that water finds its own level (Hodge 2002: 2). It was essential to keep the same gradient throughout the aqueduct's slope. Three different types of conduits were used to convey water from the springs to the cities: subterraneus rivus (subterranean), supra terram substructio (above-ground structure), and opus arcuatum (arched wall) (Póczy 1980: 39). While multi-tier bridges were built in low areas, inverted siphons were used (although rarely) in particularly deep valleys. Based on the principle of water finding its own level, this latter device worked in the following way: "The aqueduct water ran into a distribution tank, often called header basin. A row of parallel (lead) pipes left the other side of the tank and descended into the valley, crossed the bottom on a so-called 'venter' bridge and climbed up to the other side to the 'receiving' basin from which the water continued in a masonry channel to its destination" (Roman Aqueducts An Introduction). Underground pipelines were equipped with manholes for inspection and maintenance (Hansen 1983). Once the water had been directed from the springs into the aqueduct, its flow was often interrupted by settling tanks to allow sediment to sink to the bottom while other devices regulated its flow. Hubert Chanson has done pioneering work on the energy dissipation of aqueducts and identified three structures that the Romans used to ensure normal downstream flow: "(a) a smooth steep chute followed by some hydraulic jump dissipator, (b) a stepped chute, and (c) some dropshaft or dropshaft cascade" (Chanson 2000: 47-72; 2008: 10). 
Munteán, László. “The Roman Aqueduct of Aquincum in Technological and Cultural Contexts.” Hungarian Cultural Studies. e-Journal of the American Hungarian Educators Association, Volume 14 (2021) DOI:

Upon reaching the city walls, the water was led into a castellum, a large distribution tank where it would continue in multiple pipes to reach its destination in the city's fountains, baths, latrines, and households (Hodge 2002: 2).

Three different types of pipes were generally used in the conduits: a) rives per canales structiles (channels through masonry conduits), b) fistulis plumbeis (lead pipes) c) tubulis fictilibus (pipes of baked clay) (Vitruvius VIII, 6, 1.). Once the water reached the castella (distribution tanks) it was general practice to use lead pipes to supply public fountains and homes. According to popular belief, such a wide application of lead may have caused lead poisoning, which eventually contributed to the fall of Rome. Research, however, proves otherwise. Hodge argues that "There is no truth to the common belief that this caused widespread lead poisoning (although the Romans may indeed have suffered from it from other causes), for the inside of the pipes rapidly acquired an incrusted calcium carbonate coating separating the lead and the water, which was in any case in constant flow and never long enough in the pipe to make any harm from it" $(2002,2-3)$. On the other hand, illegal users' constant bribing of water officials to tap aqueducts presented a more frequent problem. As Frontinus reports,

The following mode of gaining money, practised by the water-men, is also to be abolished; the one called "puncturing." There are extensive areas in various places where secret pipes run under the pavements all over the City. I discovered that these pipes were furnishing water by special branches to all those engaged in business in those localities through which the pipes ran, being bored for that purpose here and there by the so-called "puncturers;" whence it came to pass that only a small quantity of water reached the places of public supply. How large an amount of water has been stolen in this manner, I estimate by means of the fact that a considerable quantity of lead has been brought in by the removal of that kind of branch pipes. (II, 115.)

Having outlined some typical features of the Roman aqueduct, let us now turn to the province of Pannonia and examine the water supply of the city of Aquincum.

\section{The Aqueduct of Aquincum}

Located in what is now the northern part of Buda in the city of Budapest, Aquincum was one of the most prominent settlements in the Roman province of Pannonia. Originally settled by Celtic tribes, the Romans conquered the region around AD 10 (Kaba 1963: 5). To defend the Empire's borders, the Romans built a limes, or line of fortifications, that stretched along the western bank of the Danube River. Built between 88-91 for the legio II auditrix (auxiliary legion II), the legionary fort (castrum) of Aquincum was one of the larger strongholds on the limes. Construction of the castrum was soon followed by the establishment of the canabae (military town) around it, as well as the building of a civilian settlement 2.5 kilometers (1.5 miles) to the north. In the beginning of the second century, the province was divided into an upper and a lower part. Aquincum became capital of Pannonia Inferior and started to flourish as the seat of the proconsul whose palace was built on an island (today Óbudai-sziget) close to the civilian town of Aquincum. During the reign of Hadrian, both the military and civilian towns embarked on a period of rapid development. In AD 124, the civilian town of Aquincum was awarded the rank of municipium. It was during this time period that the town was enclosed by a wall of 380 by 420 meters ( 415 by 460 yards) and served, along with the castrum and canabae further south, as a prominent settlement on the limes. During its emergence as a municipium, the 
Munteán, László. "The Roman Aqueduct of Aquincum in Technological and Cultural Contexts.” Hungarian Cultural Studies. e-Journal of the American Hungarian Educators Association, Volume 14 (2021) DOI:

town flourished with its newly built amphitheater and baths while the first aqueduct was also completed around this time (Póczy 1972: 15). Although the Quad-Markoman-Sarmatian wars of AD 167-180s caused a lot of damage, Emperor Septimus Severus granted Aquincum the status of colonia in 194. This privilege marked the beginning of new constructions that were, in some cases, even more opulent than previous ones had been. Nevertheless, by the end of the fourth century, when Pannonia was divided into four regions, Aquincum had already begun to decline and the seat of the proconsul was moved to Sopianae (today Pécs). Aquincum did not live to see the end of the Roman Empire. Upon his visit to the province, Emperor Valentinianus found the towns of Pannonia in ruins while Aquincum was a ghost town without a single building fit for him to stay for the winter. Mostly destroyed by migrating tribes and abandoned by its population, the town was officially ceded to the Huns in 409 (Kaba 1963, 5-7).

Long after the fall of the Roman Empire, the ruins of Aquincum represented a puzzling mystery for visitors. Although no longer conveying water, the remains of the aqueduct would serve as a landmark on maps throughout the upcoming centuries. For instance, the medieval chronicler Anonymus mentions the Hungarian leader, Árpád, mistaking the aqueduct for some magnificent edifices built by the legendary Attila the Hun (Kaba 1976: 225). Later it was mentioned as a property boundary marker in a letter of inspection of boundaries issued by Louis of Anjou in 1355 (Foerk 1923: 36). Some sixteenth- and seventeenth-century etchings show the arches of the aqueduct at their full height, while the Italian military engineer, Count Marsigli, who reported in great length and detail on the siege of Buda in 1684-1686, mentions (albeit mistakenly) that the aqueduct continued farther north of Rómaifürdö (38). Although the midnineteenth century witnessed the emergence of archaeological interest in the aqueduct, it was not until Ernö Foerk's in-depth study of its ruins in the 1920s that the documentation and systematic research of the aqueduct commenced $(40,48)$. By now, the very same piers that Foerk could still see as reaching the height of three meters at some points have disintegrated almost beyond recognition (Póczy and Hajnóczy 1960: 15). The actual length and track of the aqueduct, however, would puzzle archaeologists for long decades. What seems to be certain is that it started from today's Rómaifürdő, the area replete with thermal springs, and ran southward crossing the civilian settlement all the way to the amphitheater of the canabae at what is now Nagyszombat Street.

Based on the archaeological excavations that have taken place in the area, in the following paragraphs I will trace the remains of the aqueduct from its springs to the point where it supposedly ends. Throughout her career as an archaeologist, Klára Póczy (1923-2008) has done pioneering work in the excavation and restoration of Hungary's Roman heritage. She is particularly famous for her research into the system of public utilities in Pannonia and the springs that fed the aqueduct of Aquincum in particular. Until her excavations in the area of Rómaifürdő conducted between 1959-1964, virtually nothing had been known about the springs that supplied water for the aqueduct.

A land survey carried out in the time of Habsburg emperor Maria Theresa prior to the construction of a gunpowder mill provided the coordinates necessary for the commencement of Póczy's excavation. Dated from 1778, the map drawn by military engineer Lindenhof indicates some "ruins of old buildings" in the area that clearly indicates a wall around the springs the layout of which was reminiscent of a Roman castrum (Póczy 1972: 15; 1980: 55). Other than the eastern segment of this wall, archaeologists exposed the sturdy remains of the beginning of the aqueduct as well as the foundations of a stone tower. The subsequent redevelopment of the 
Munteán, László. “The Roman Aqueduct of Aquincum in Technological and Cultural Contexts.” Hungarian Cultural Studies. e-Journal of the American Hungarian Educators Association, Volume 14 (2021) DOI:

recreational area of what is now Római Strandfürdö ['Római open bath'] in 1962 provided an even better opportunity to study the springs, although earlier construction work had already destroyed or substantially damaged a number of valuable sites (Póczy 1972). Around each spring, wooden posts arranged in a rectangular fashion for the purpose of supporting the spring chambers had been unearthed. At the mouth of each spring, the Romans installed cone-shaped terracotta intakes around which the floor was meticulously covered with layers of clay, gravel, and stone panels so the water could only find its way through the intake. The intake at spring IX survived in the best condition (Póczy 1972: 16-17). From the fourteen springs, stone channels led the water to a meter-wide ( 3.28 feet) main conduit that was covered with bricks in a fishbone pattern (Fig. 1.). At the southernmost junction, the water was pumped into a tower from which it flowed into the arched aqueduct that would lead the water southward for about five kilometers (3.1 miles) with an average slope of 4.1-4.2\% (24-25). Although inventions such as piston pumps and waterwheels had already been at the Romans' disposal for pumping water to higher elevations (Póczy 1980: 68-69), the actual method of this operation in Aquincum remains unclear. In all probability, the terracotta intakes were made in one of the pottery workshops of the legio II auditrix, whose seal was identified in many of the bricks used in buildings around the source area. It is thus highly probable that the terracotta intakes were also made in one of the canabae's workshops in the second half of the second century. Analogies to the woodwork used in the spring chambers can be found in the Roman ports of Xanten, Ostia and at Lake Nemi (43).

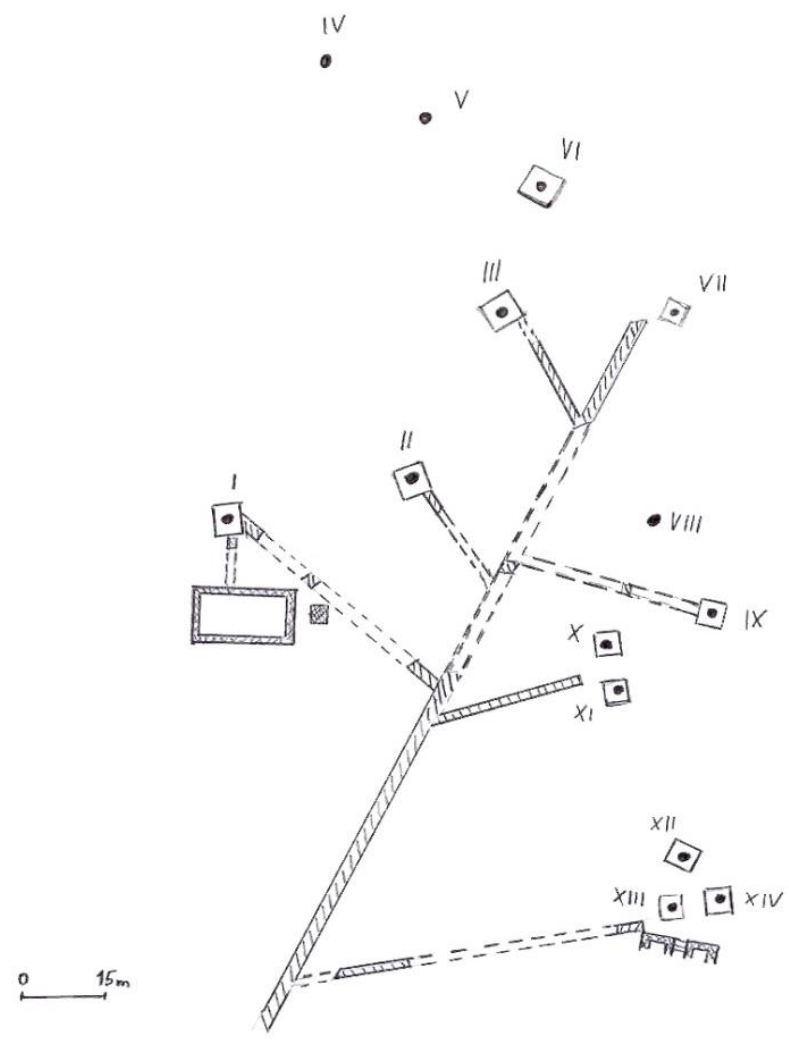

Fig. 1. Location of spring chambers and channels at the aqueduct's source (re-drawn by the author based upon illustration in Póczy 1984: 12) 
Munteán, László. "The Roman Aqueduct of Aquincum in Technological and Cultural Contexts.” Hungarian Cultural Studies. e-Journal of the American Hungarian Educators Association, Volume 14 (2021) DOI:

The complexity of the construction of the intakes must have required the skills of an expert. In written records related to construction work at Aquincum, the word mensor was used to denote a land surveyor. The expression discentes mensores, however, signified an engineer specializing in a certain field. On one of the altar stones, the term discens regulatorum may refer to an expert leading a team that worked with a protractor (regula). Moreover, not only the expertise, but also the financial resources needed to cover the exorbitant expenses of building an aqueduct had to be raised before construction could commence. It is no wonder that the emperor's permission was indispensable to beginning such a project (Póczy 1972: 27-28). It is believed that the civilian and legionary towns equally took a share in procuring the financial resources necessary for the completion of the project. Under the administration of the city council, whose responsibility it was to organize the construction, a fairly large percentage of the population of Aquincum must have been involved: stonemasons, potters, brick- and lead-makers, carpenters, braziers and artisans of all sorts had to put their shoulders to the wheel throughout this enormous undertaking. Special teams were responsible for the maintenance of the aqueduct and the administration of water distribution in the settlements. Although legally two separate towns, such an enterprise definitely drew the municipium and the canabae closer after the QuadMarkoman-Sarmatian wars. By the time Aquincum became a colonia at the end of the second century, the system of public utilities had been sufficiently brought up to standard.

Before moving on to examining the aqueduct itself, let us briefly return to the source. We have already seen the advanced technology the Romans used for the catchment of spring water. The site of the springs, however, also had a cultic significance. In some chambers, altar stones, many of which still stand in situ, have been recovered. These altar stones suggest that many gods were worshipped in the area and the rituals associated with these deities corresponded with the topographical arrangement of the spring chambers that also served as sanctuaries. At the entrance of the "sacred grove," stairs led to the altar of Jupiter. The spring chambers located in the vicinity of the entrance held altar stones dedicated to Aesculapius and Hygieia or Apollo and Sirona. Found in the best condition, spring chamber IX was dedicated to Silvanus and was also in the vicinity of the entrance. Farther north, altars dedicated to Mithras and Sol Invictus (Unconquered Sun) have also been identified. Apollo appears in the form of the Celtic god Grannus, which Póczy sees as a manifestation of the blending of Celtic cultural heritage into Roman rituals (1984: 13). The veneration of these deities attests to the ritual dramatization of the healing power of water as a source of life on the one hand and light, which represents fertility and life, on the other. Normally, aqueducts were associated with the Nymphs, but this was not the case in Aquincum. Póczy suggests that, here, it is highly probable that the locals had revered these gods long before construction of the aqueduct and their cult survived even after the aqueduct was built (14). Throughout the first half of the third century, sacrifices were performed at all of these locations. Worshipping the gods took place in the open. It was also essential that the water remain clean, a factor that was ensured by the spring chambers (sanctuaries) with protective antefixes in their gables featuring lion heads in the wreath of rays, an element that appeared on shields and armor in the age of the early emperors (15).

Located west of the sanctuaries, stone foundations of a larger wooden building with a length of one hundred-twenty meters (394 feet) and a width of 30 meters (98 feet) have also been uncovered. This structure received its water supply through a stone channel coming from spring chamber III and is believed to be a temporary shelter (Póczy, 1980: 15) or hospital (Zsidi 2002: 60). The sacred grove was also the destination of parades and processions (Póczy 1984: 24-25). 
Munteán, László. “The Roman Aqueduct of Aquincum in Technological and Cultural Contexts.” Hungarian Cultural Studies. e-Journal of the American Hungarian Educators Association, Volume 14 (2021) DOI:

With the advance of Christianity, the area lost its function as a cultic site and the statues of deities were presumably destroyed as pagan idols (1980: 104). In the fourth century, the enclosing wall was turned into a fortification.

Research of the site's archaeological treasures resumed in 2000. Led by Orsolya Láng, archaeologists differentiated at least five construction periods in the area. Apart from the foundational walls of the old Tóvendéglö ['Lake-Side Restaurant'], a famous restaurant from the 1920s, segments of the gunpowder mill from the time of the Habsburg Emperor, Maria Theresa, were also uncovered. Construction of this self-same mill was preceded by Lindenhof's survey of 1778 , the source indicating the site of "ruins of old buildings" that had served as a point of reference for Póczy's excavations between 1959-64. The excavation in 2000 also revealed some medieval wall fragments and the wooden posts of a spring chamber, as well as a wall presumed to be adjacent to the so-called "western shrine" unearthed in the vicinity of spring no. I. in 1965. In addition, about six meters (6.5 yards) west of the foundation of the aqueduct, a 190centimeter-wide ( 6.2 feet) cast wall was also uncovered, even though its relation to the previously unearthed ruins remains unclear (Láng 2002: 54-58).

Let us now follow the track of the water and see how it reached the municipium and the canabae. As I have already noted, at the point where the water from the southernmost spring chamber flowed into the main one, a water tower was built, thereby marking the beginning of the arched aqueduct. In the territory of Hungary, Aquincum was the only settlement to boast of an aqueduct resting on arches. In other settlements, such as Brigetio (today Ószőny) and Savaria (today Szombathely), aqueducts were put on arches only in hilly or swampy environments. Water pipes running in underground trenches covered with vaulted, gabled or corbelled roofs were much more widespread (Póczy 1980: 65). The aqueduct in Aquincum maintained a reasonably fixed slant of 4.1-4.2\% and ran southward for more than five kilometers (3.1 miles) to supply the canabae's baths and fountains. The distance between the piers was 280-300 centimeters (9.2-9.8 feet) and the arches' rise was one-and-a-half meter (4.9 feet) (62). The piers were generally 160 centimeters long (5.2 feet) and 110 centimeters ( 3.6 feet) wide, except at places where alterations to this standard had to be implemented, for instance at the point where the aqueduct enters the municipium at its northern wall and stretches over a wider trench. Once inside the civilian town, the aqueduct ran along the western edge of the main street constituting a monumental landmark that divided the whole settlement into two parts. Although its parameters and exact location remain unknown, a distribution basin was built at the northern wall of the civilian town (76) with another one in the canabae as well. According to Melinda Kaba (1976: 227), these castella were generally built in accordance with Vitruvius's directions, who gives the following instructions:

From this central tank, pipes will be laid to all the basins and fountains; from the second tank, to baths, so that they may yield an annual income to the state; and from the third, to private houses, so that water for public use will not run short; for people will be unable to divert it if they have only their own supplies from headquarters. This is the reason why I have made these divisions, and also in order that individuals who take water into their houses may by their taxes help to maintain the conducting of the water by the contractors. (Vitruvius VII, 6) 
Munteán, László. "The Roman Aqueduct of Aquincum in Technological and Cultural Contexts.” Hungarian Cultural Studies. e-Journal of the American Hungarian Educators Association, Volume 14 (2021) DOI:

Hodge, on the other hand, remains skeptical about the applicability of this system and emphasizes the overall vagueness of this oft-quoted passage (2002:3). What is certain is that lead pipes imbedded in mortar were used in abundance in Aquincum to supply baths and fountains with water in a way that was similar to the water system of Pompeii. The castrum had its own water tank installed in the superstructure of the gate leading to the military headquarters. The two floors above the arches of the gate served as water tanks while the pipes were laid in the basement (Póczy 1980: 78).

Other than the aqueduct running in a north-south direction, the canabae also had another one running in a northeast-southwest direction. Supplied by springs at the nearby hillside, excavations at 73-75 Vörösvári Road have provided evidence that this facility featured the same structure as the one with the north-south direction. However, the main line of this second conduit had more turns to regulate the flow of water and crossed the castrum in a diagonal fashion with numerous pipelines branching off to the northwestern and southeastern parts of the canabae. While the aqueduct coming from the north had three lines of clay pipes running parallel, this latter one only had two (Wellner 1973: 179-181; Póczy 1980: 64-65).

The towns of Pannonia were also equipped with an advanced sewerage system the construction of which was often more complicated than that of the aqueducts. Aquincum provides an array of solutions to this problem. In the civilian town, sewage water was led into a dry ditch outside the city walls which led to the main sewage conduit running in the direction of the Danube. Within the city, main sewage canals ran on both sides or in the middle of the main streets branching off to the latrines of the individual buildings at right angles. At crossings, manholes were provided for maintenance. In the castrum and in the canabae, canals merged with the main sewage conduit at sharp angles pointing towards the flow (Póczy 1980, 80). Among the various sorts and types of sewage conduits, the ones that channeled both rainwater and sewage represented the highest technology. They would generally run one-and-a-half or two meters (56.5 feet) under the street level with the other pipes merging with them at sharp angles. Stamped bricks used in the construction of these systems date their construction to AD 211 (84).

The operation of the aqueducts required a complex bureaucracy that ensured its proper functioning. These tasks were generally threefold: a) administrative (issuing permits, responding to complaints, organizing inspections, calculating and administering the collection of water charges), b) maintenance-related (reparation works on the aqueduct and related buildings, inspection of the quality of water, providing precautions in case of floods), c) organizational (inspection of completed tasks). Attending to these tasks was the responsibility of the city council, and the aedilis in particular. Throughout the second and third centuries, the water system in Aquincum was renovated and extended every twenty-thirty years. Archaeological evidence reveals the innumerable repairs carried out on the channels and pipes, which well illustrates the heavy usage to which the system was exposed (86-87).

Outside the city walls, a "safety strip" ran along the aqueducts designated by stone markers called cippi. Although Hodge states that cippi were primarily used to mark the location of underground aqueducts for maintenance staff and were particular to the city of Rome (2002: 103), Póczy suggests that in the case of Aquincum's water supply it was part of the system of organizing the defense of the aqueduct in times of danger (90). What happened to the aqueduct once the town's heyday had passed? 
Munteán, László. "The Roman Aqueduct of Aquincum in Technological and Cultural Contexts.” Hungarian Cultural Studies. e-Journal of the American Hungarian Educators Association, Volume 14 (2021) DOI:

\section{The Aqueduct of Aquincum Today}

When driving along Szentendrei Road, one can notice a long line of amorphous rock formations in the grassy strip between the busy car lanes. These formations sit one behind the other like massive rocks, more reminiscent of works of nature than man-made structures. Once we reach the excavated section of the civilian town, these strange forms appear as part of the arched aqueduct, a section of which has been reconstructed in front of the old Aquincum Museum. Still, the size and dimensions of these rocks hardly seem to fit into the delicate arches of this reconstructed section. If these awkward shapes are part of the piers of the aqueduct, how come they do not fit the original structure?

It has already been mentioned that the aqueduct ruins served as a visual reference point after the fall of the Roman Empire. In the time of Louis of Anjou, the ruins had been used as landmarks to designate property boundaries while an eighteenth-century land survey identifies them as reference points for the construction of a gunpowder mill whose remains were identified during the excavations at Rómaifürdö in 2000-2001. Although the ancient structure was probably still distinctly visible in the eighteenth century, it was on the verge of disappearing completely due to redevelopment of the area in the second half of the nineteenth century. Had it not been for the intervention of the National Council of Monuments in 1878, they would have vanished entirely. As a result, the construction of the $H E ́ V$ [a suburban railway line between Budapest and Szentendre] and the Budapest-Esztergom railway in 1888 was carried out without causing further damage to the ruins (Foerk 1923: 35). Moreover, a council was established for the preservation of the above-ground remains of the piers (Kaba 1976: 225).

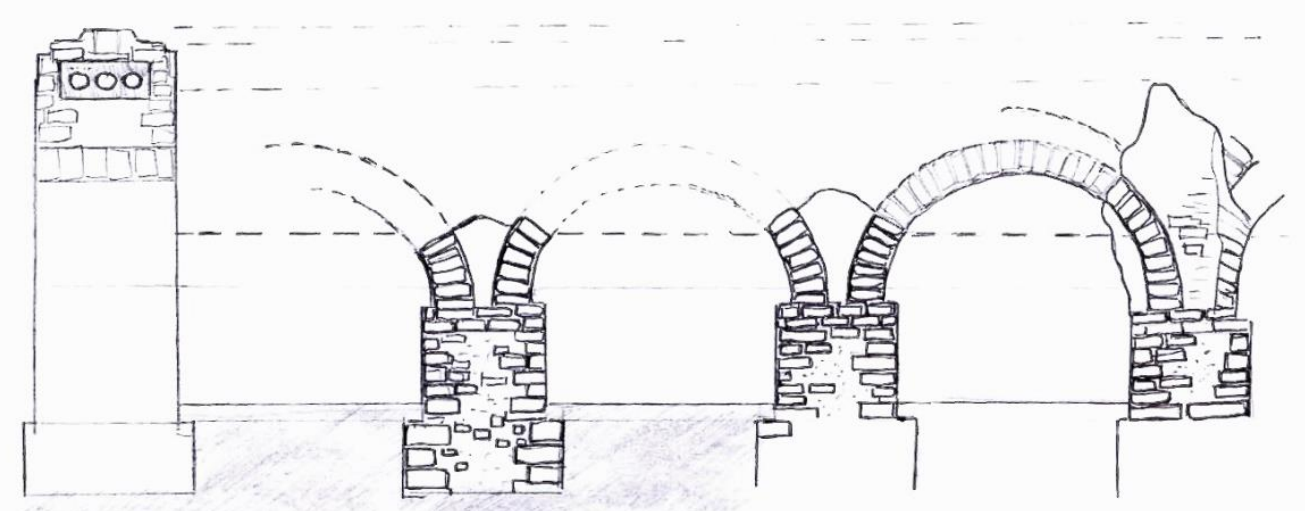

Fig. 2 Reconstruction of a typical section of the aqueduct's arches (re-drawn by the author based upon illustration in Foerk 1923: 48)

Although in the second half of the nineteenth century quite a number of archaeologists immersed themselves in studying the remains of the aqueduct, it was not until Foerk's in-depth research during the 1920s that the ruins were documented in detail. On a 2,300-meter-long (1.4 mile) section between the source at Rómaifürdő and the last above-ground pier, he registered over five hundred piers and documented their parameters. His drawings also illustrate that the spherical formations, the "rocks" now visible in the green strip between the car lanes on Szentendrei Road, are in fact multiple layers of calcium carbonate precipitated from cavern water 
Munteán, László. "The Roman Aqueduct of Aquincum in Technological and Cultural Contexts." Hungarian Cultural Studies. e-Journal of the American Hungarian Educators Association, Volume 14 (2021) DOI:

coming from the springs (Fig. 2). This means that the small-scale, Stonehenge-like blocks that we can see along the road today are not the piers per se, but rather the layers of sediment that collected around them. Long after the fall of the Roman Empire, water still flowed through the aqueduct's conduit but, due to centuries of neglect and disrepair, ended up seeping through the cracks and eventually deposited layers of sediment that wrapped the piers (Kaba 1976: 227). Nevertheless, reasons for the almost complete disappearance of the pier's masonry are to be found elsewhere. Because the aqueduct's dressed stones proved to be valuable for new construction throughout subsequent centuries, the ashlars had been quarried out of the useless slabs of petrified calcium carbonate. Foerk mentions that the Óbudai Szent Péter és Pál Föplébánia templom ['St. Peter and Paul Parish Church of Óbuda'] was built almost entirely from the stones of the aqueduct (5). The amorphous forms that could not be used for building purposes remained in situ as literal "negatives" of the masonry that they had once surrounded. By "bearing witness" to what is already absent, the imprints preserved in these sediment blocks have been instrumental in helping archaeologists calculate the arches' rise, the radius of their haunch and construction of the skewback on the piers (Fig. 3-4). Foerk also notices that at certain sections of the aqueduct, such as the one close to the source and the other that cuts through the civilian town, a 45 -centimeter-thick (18 inches), continuous wall was built in between the arches that, in some places, covered the full rise of the arches (49).

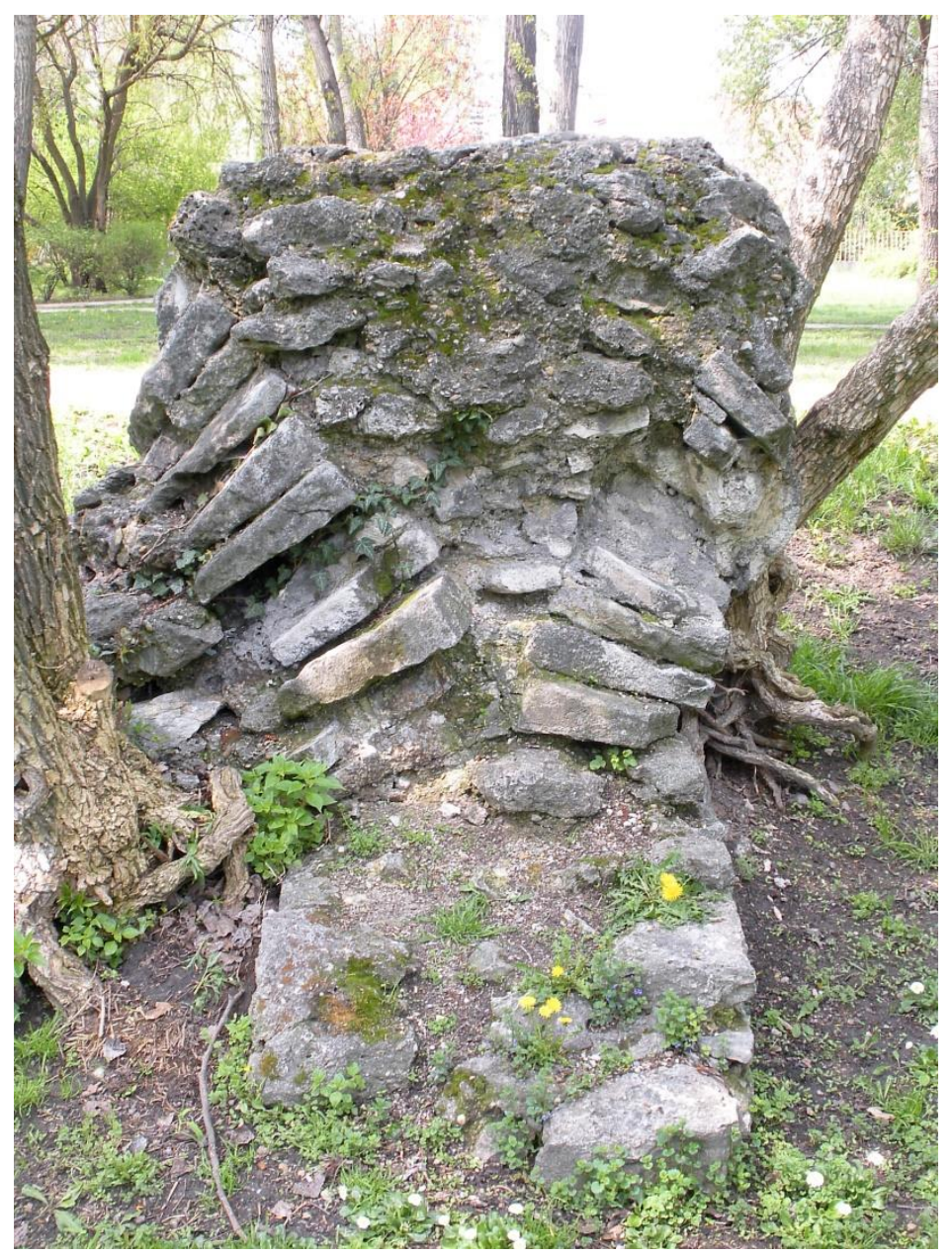


Munteán, László. "The Roman Aqueduct of Aquincum in Technological and Cultural Contexts." Hungarian Cultural Studies. e-Journal of the American Hungarian Educators Association, Volume 14 (2021) DOI:

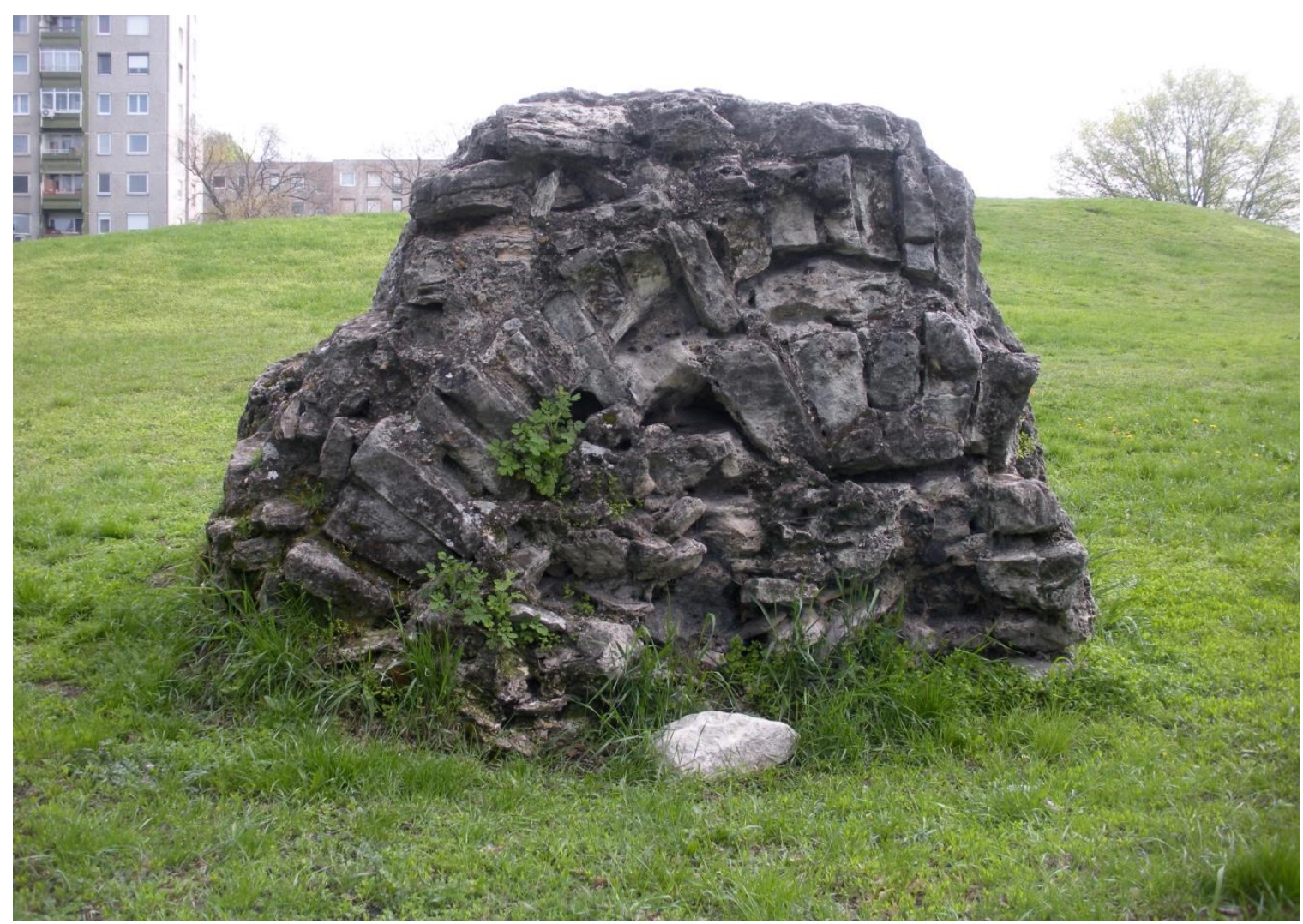

Fig. 3-4 Fragments of the aqueduct's arches preserved in sediment (photo by author)

Research on the piers resumed during the construction of the Auchan supermarket on Szentendrei Road in 2003. Led by Zoltán Havas, the excavation confirmed the results of Ernö Foerk and Melinda Kaba's previous observations. Due to the construction of a road junction, preliminary excavation work also had to be done for the removal of the sediment formations around two piers (number 67 and 68 in Kaba's numbering system 1976: fig. 61) just north of the level of Záhony Street. Havas concludes that,

It could be observed in the case of the blocks removed in 2003, which originally lay east of pillar 67 and west of the space between pillars 67 and 68 that the aqueduct was already in need of repair before the blocks developed. The arch between the pillars was supported or replaced by a wall raised perpendicular to the line of the aqueduct. The soft, spongy blocks, which were not suitable for building purposes, and the dressed stone blocks stuck in them were left alone in the Modern period when stone was quarried from the aqueduct. This is how 1-2 stone rows of the western edge of pillar no. 67 survived with the start of the arches, just like a few blocks from the arch between pillars 67 and 68 as well as their impressions together with the stone blocks and the later wall and their imprints. (2004, 63-64)

The lifting of the "sediment blocks" and their installation at their new location in front of the building of the Aquincum Museum in Záhony Street were carried out according to the 
Munteán, László. "The Roman Aqueduct of Aquincum in Technological and Cultural Contexts.” Hungarian Cultural Studies. e-Journal of the American Hungarian Educators Association, Volume 14 (2021) DOI:

plans of István Harsányi and Ágnes H. Vladár. For the sake of a didactic presentation of the slabs, "The surfaces of the pillars are emphasized by a ground cover of large pebbles placed individually into a soft concrete bed, while the zone that connects the pillars, which is actually the projection of the arches of the aqueduct, is indicated by white limestone rubble" (Vladár 2004: 70). The imprints of the stones that once formed the arch of the aqueduct and were preserved as negatives allow visitors to see a segment of the ancient construction from within. As the volume of sediment exposes the remaining skewbacks and voussoirs from within, absence becomes an uncanny presence not unlike those victims of the eruption of the Vesuvius in Pompeii in AD 79 whose bodies were preserved as voids in the ash layer.

Bearing some typical features of architect László Rajk's radical eclecticism, the façade of the museum further intensifies this effect. By way of mimicking a line of arched arcades that suddenly breaks off at the protrusion of the entrance, the process of ruination is dramatized in a postmodern fashion. Just as the imprints in the sediment blocks evoke the structure of the aqueducts' arches, so does the broken line of the arcaded façade allude to a larger structure of which it is a fragment. Yet Rajk's "ruinous" façade does more than that in this context. By way of embodying characteristics familiar to classical arches, it becomes a pastiche that renders itself kitsch in the face of the original slabs exhibited in front of the entrance. But if kitsch (both nostalgically and ironically) evokes the aura of those objects that it mimics, Rajk's design subliminally comments on the displacement of the piers from their original location, as an instance of shattering their aura granted to them by their location in situ. At the same time, Rajk's use of kitsch also comments on the role of pre-existing narrative schemes that we apply when trying to contextualize fragments. Either way, such an architectural arrangement that contextualizes the exhibition of the displaced blocks of sediment in postmodern kitsch undoubtedly creates a unique manifestation of the past's integration into the present and is therefore worthy of attention (Fig. 5). Redesigned by the same architect from a classicizing distribution station built in 1931, the new exhibition hall of the Aquincum Museum further illustrates this dynamic. ${ }^{1}$

${ }^{1}$ For the architect's statement see: http://rajk.info/hu/epiteszet/aquincumi-muzeum-projekt-ii.html (accessed: April 10, 2021) 
Munteán, László. "The Roman Aqueduct of Aquincum in Technological and Cultural Contexts.” Hungarian Cultural Studies. e-Journal of the American Hungarian Educators Association, Volume 14 (2021) DOI:

10.5195/ahea.2021.424

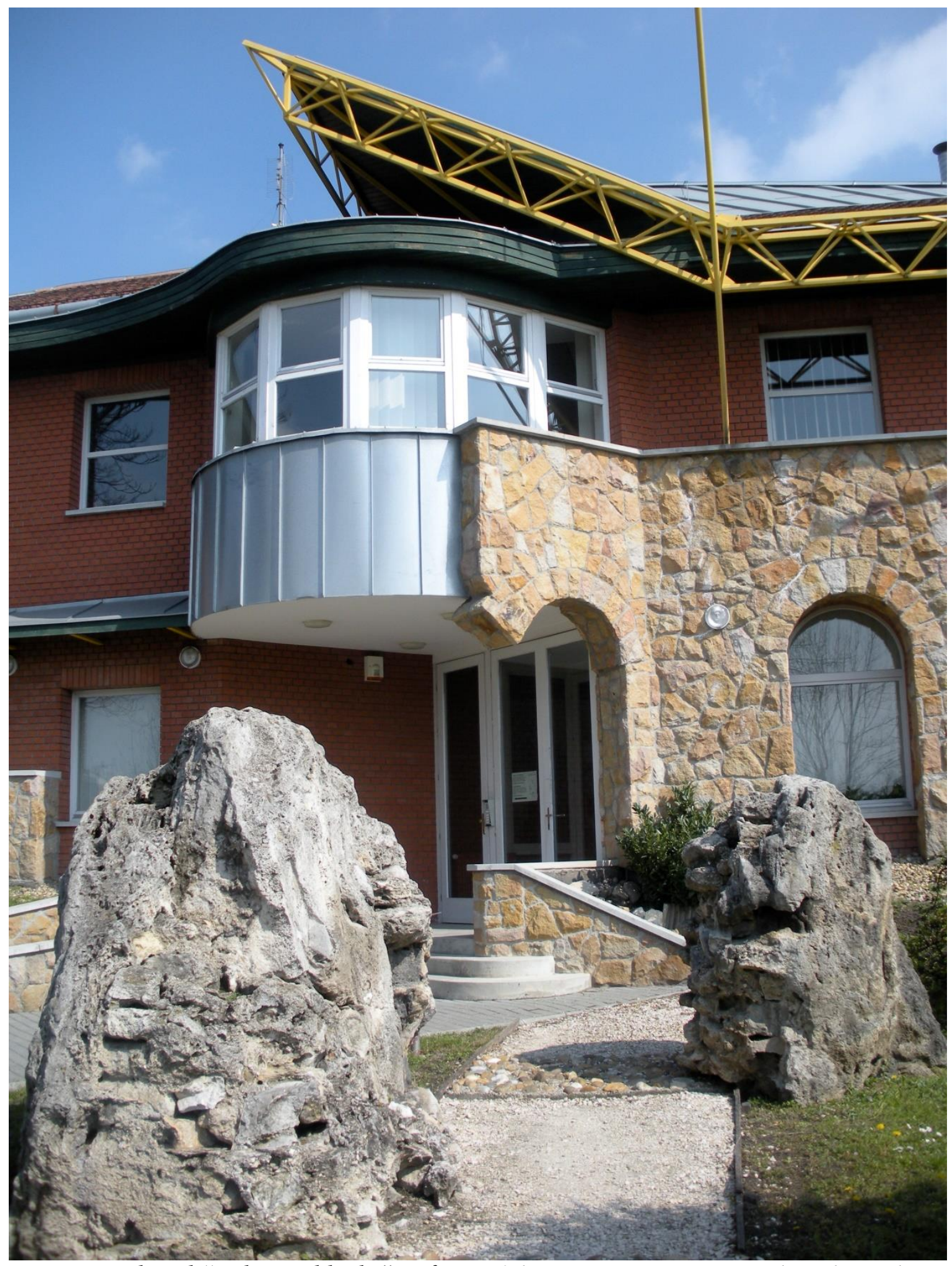

Fig. 5 Displaced "sediment blocks" in front of the Aquincum Museum (photo by author) 
Munteán, László. "The Roman Aqueduct of Aquincum in Technological and Cultural Contexts." Hungarian Cultural Studies. e-Journal of the American Hungarian Educators Association, Volume 14 (2021) DOI:

Let me conclude by returning to the southernmost visible remnant of the aqueduct, a large rock formation known as Mária kö ['St. Mary's Rock'] and explore the history of its name. During the flood of 1811, a stonemason called Jakab Bauer fished out a painting from the Danube and placed it on the rock, which had a grotto-like appearance due to centuries of calcium carbonate precipitation from the former aqueduct. The image that Bauer found was a copy of Lucas Cranach's famous Maria hilf ['Helping Madonna'] located in Innsbruck, Austria. Soon afterwards, the site became a shrine and the painting received a metal cabinet with a curved baroque roof installed in the rock (Fig 6).

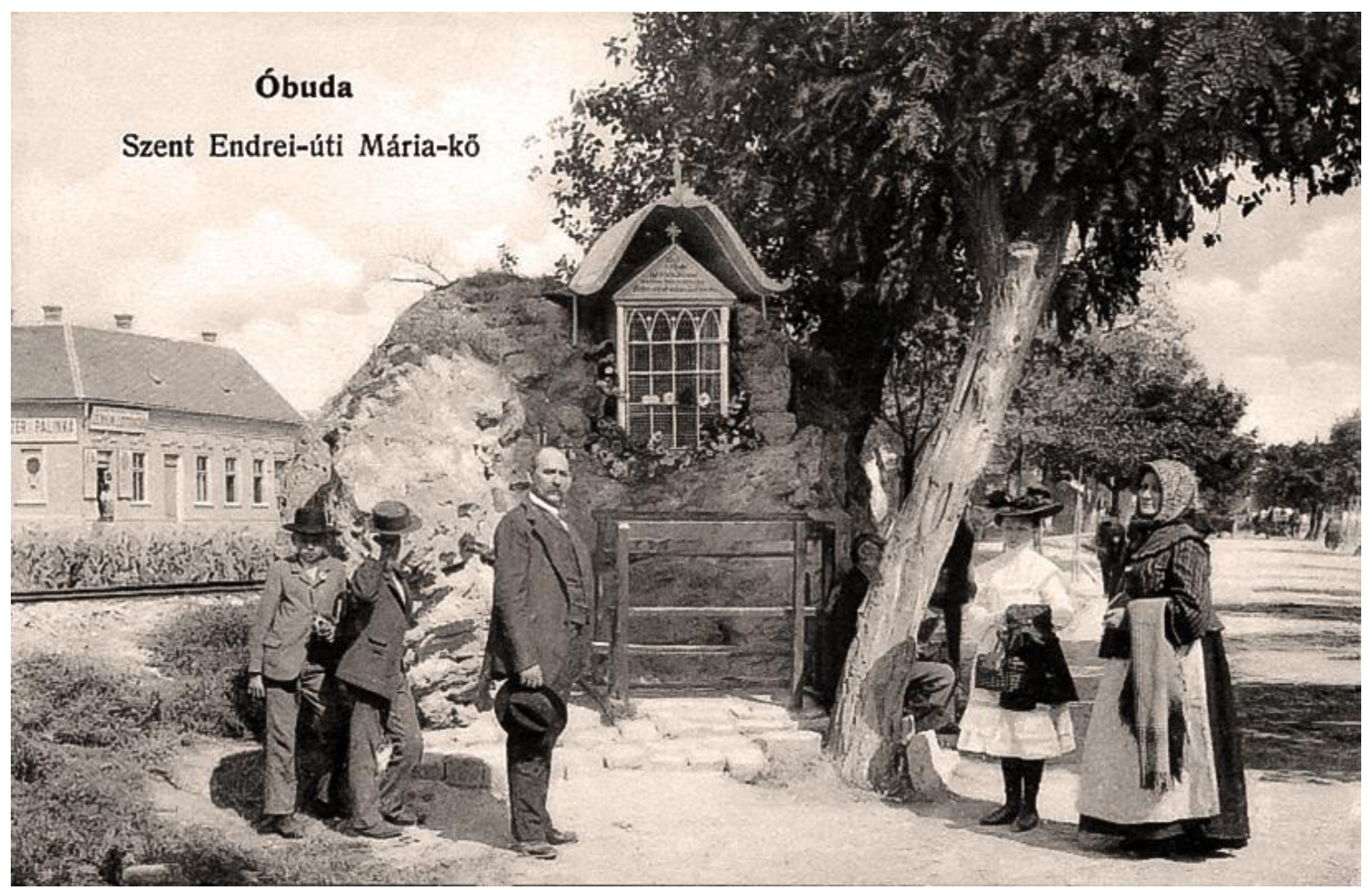

Fig. 6. The shrine of Mária kö in the early twentieth century http://kepeslapmuzeum.hobbipark.hu/tag/maria-ko/

In 1865, a small church dedicated to the Virgin Mary of the Rock was built further north of Mária kö. On the hundredth anniversary of Bauer's discovery, the original painting in the cabinet was moved into the church and a copy was put into the shrine as a replacement (A Kövi Szüz Mária Plébániatemplom és Egyházközség története - the parish's website). During the landscaping of the area in 1932, the shrine was scheduled to be bulldozed but was ultimately spared thanks to the resourcefulness of the parish priest, Lajos Peisz, who, with the support of helping hands from the Council of Monuments, managed to cut the stone and move it ten meters away from its original site. The shrine's tribulations did not end here, however. Construction of an overpass on Szentendrei Road posed further difficulties that led to the abandonment of Mária $k \not ̋$ due to its inaccessible location between two busy thoroughfares. By the early 2010s, the shrine's cabinet was already rusting away and the rock had been overgrown with weeds and shrubs, providing a safe hiding place for the homeless (Fig. 7). 
Munteán, László. "The Roman Aqueduct of Aquincum in Technological and Cultural Contexts." Hungarian Cultural Studies. e-Journal of the American Hungarian Educators Association, Volume 14 (2021) DOI:

10.5195/ahea.2021.424

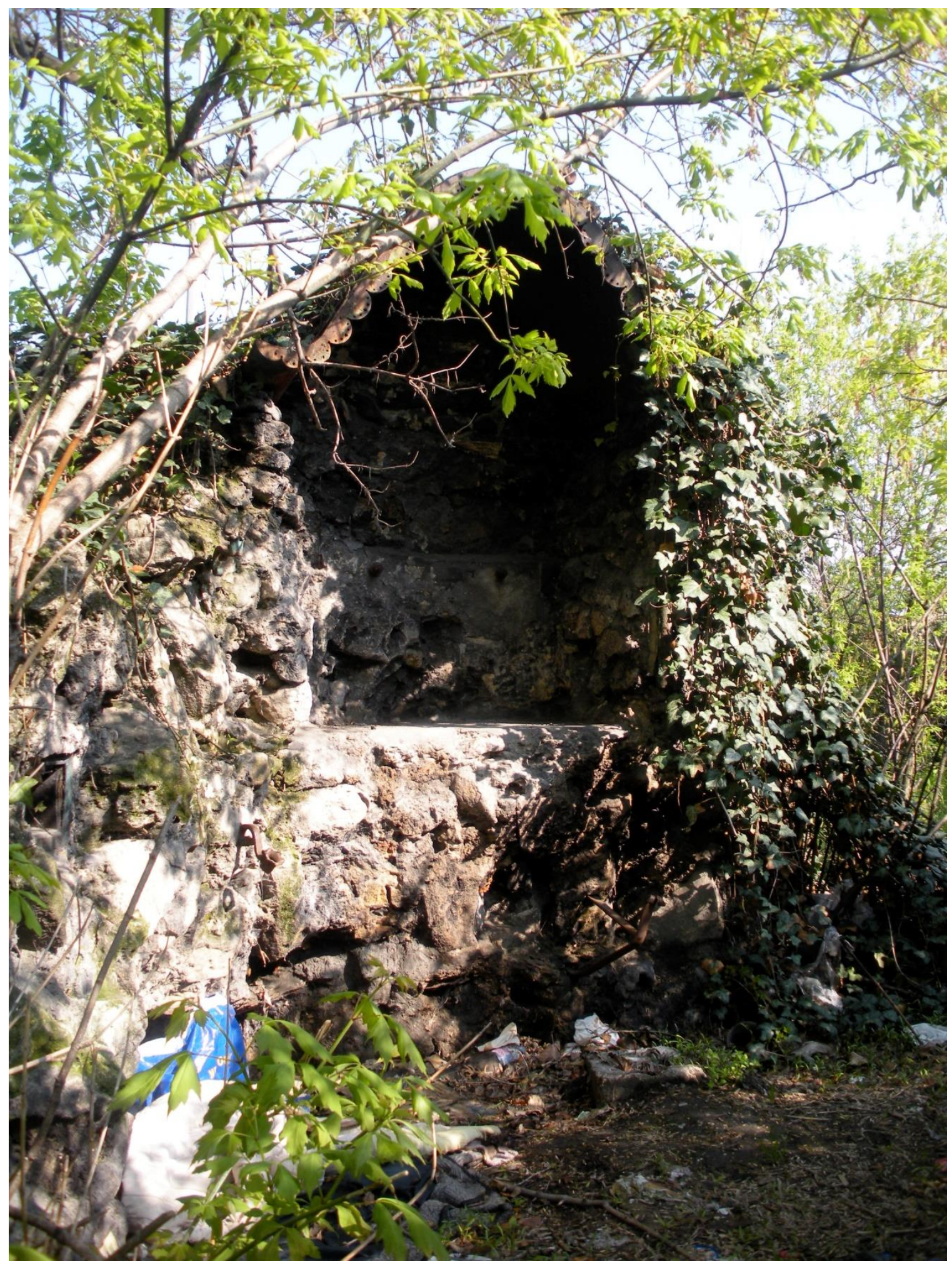

Fig. 7 The shrine as it looked before the renovation in 2012 (photo by author) 
Munteán, László. "The Roman Aqueduct of Aquincum in Technological and Cultural Contexts." Hungarian Cultural Studies. e-Journal of the American Hungarian Educators Association, Volume 14 (2021) DOI:

Even if disused with the copy of the painting long gone from its damaged cabinet, the site had provided a sense of safety for those in need, a function that still resonated with the message of the original painting placed there by Bauer. In 2012, however, the area around the church underwent a complete renovation and the shrine was restored to its former beauty. Sadly, however, the mosaic replica of the original painting, created by patients in a home for the disabled, was stolen shortly after the renovation. The image that it now holds is a photographic copy of the original painting inside the church (Fig. 8).
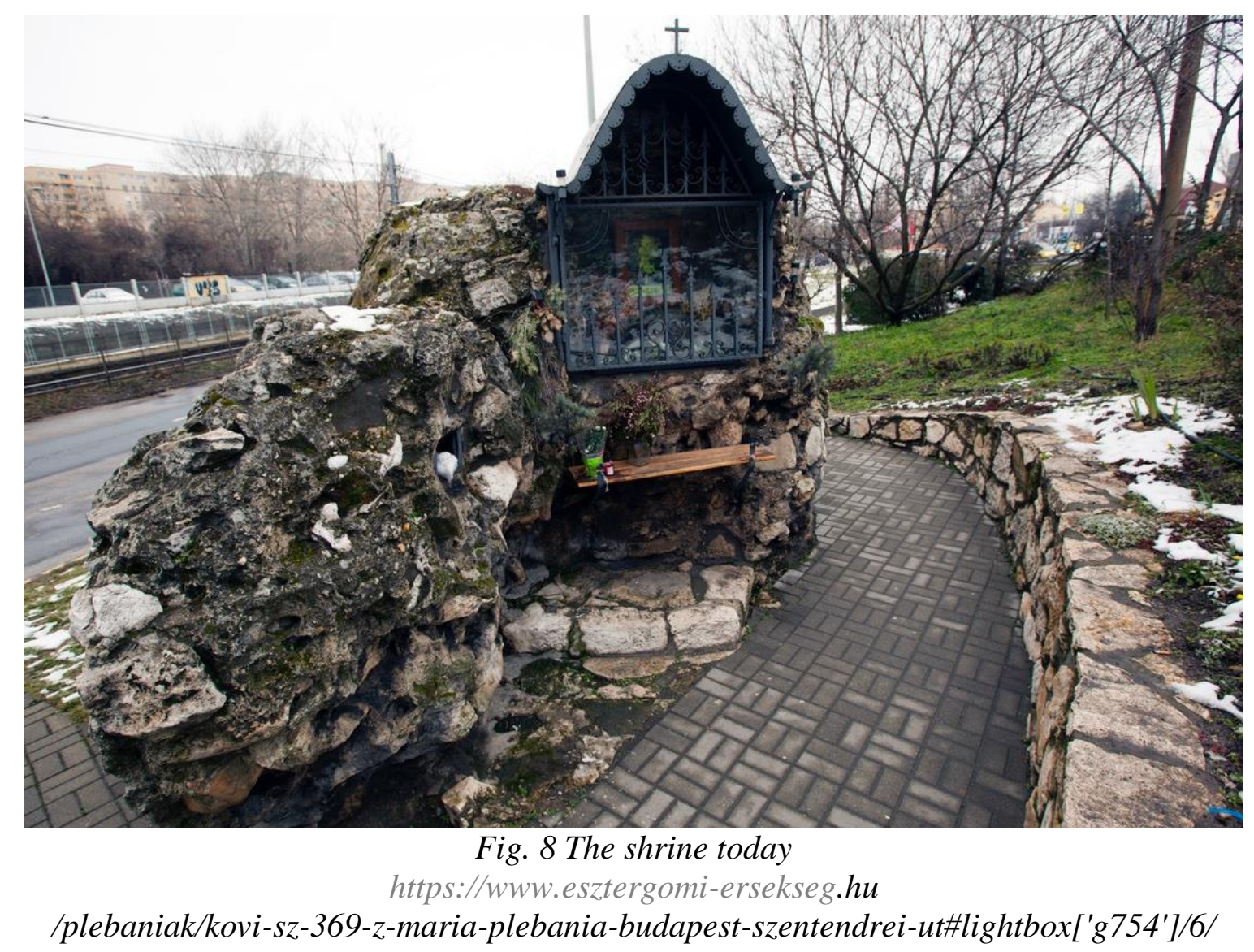

For all the vicissitudes of its history (or perhaps because of them), the Mária kö is a telling example of how the ruins of ancient Rome have served subsequent centuries as foundations for new beginnings. The aqueduct that carried water from the sacred grove to the municipium and the canabae has not simply yielded archaeological finds to learn about ancient Aquincum, but also provided the cornerstone of a new religious practice that is still alive.

\section{Works Cited}

Ashby, Thomas and I.A. Richmond. eds. 1935. The Aqueducts of Ancient Rome. Oxford: Clarendon Press.

Barkóczy, László, Bóna István, Mócsy András, Harmatta János, eds. 1963. Pannónia története ['The History of Pannonia']. Budapest: Tankönyvkiadó. 
Munteán, László. "The Roman Aqueduct of Aquincum in Technological and Cultural Contexts.” Hungarian Cultural Studies. e-Journal of the American Hungarian Educators Association, Volume 14 (2021) DOI:

Chanson, Hubert. 2000. "Hydraulics of Roman Aqueducts: Steep Chutes, Cascades, and Dropshafts." American Journal of Archaeology 104,1 (January): 47-72.

---. 2008. The Hydraulics of Roman Aqueducts: What Do We know? Why Should We Learn? Plenary lecture, ASCE-EWRI Education, Research and History Symposium, Hawaii, USA, Keynote lecture, 13-16 May 2008. http://espace.library.uq.edu.au/eserv/UQ:138266/ewri08_k.pdf (Accessed: April 10, 2021)

Foerk, Ernő. 1923. “Az óbudai aqueductus” ['The Aqueduct of Óbuda']. Budapest Régiségei ['Antique Sites of Budapest'] 10: 19-45.

Frontinus, Sextus Julius. The Aqueducts of Rome. Annotated by Bill Thayer http://penelope.uchicago.edu/Thayer/E/Roman/Texts/Frontinus/De_Aquis/text*.html (Accessed: April 10, 2021).

Hansen, Roger D. 1983. "Water and Wastewater Systems in Imperial Rome." JAWRA: Journal of the American Water Resources Association 19,2: 263-269.

Havas, Zoltán. 2004. "Feltárás a Szentendrei úti aquaeductus nyomvonalán” ['Excavation Along the Aqueduct on Szentendrei Road]. Aquincumi Füzetek ['Notebooks of Aquincum'] 10: 61-65.

Hodge, Trevor A. 2002. Roman Aqueducts and Water Supply. London: Duckworth.

Kaba, Melinda. 1963. Aquincum emlékei ['The Antiquities of Aquincum']. Budapest: Képzőmüvészeti Alap Kiadóvállalata.

---. 1976. “Az aquincumi aquaeductus pilléreinek 1975. évi kutatása (előzetes jelentés)” ['The 1975 Excavations of the Piers of the Aqueduct at Aquincum: A Preliminary Report']. Budapest Régiségei 24: 225-230.

A Kövi Szüz Mária Plébániatemplom és Egyházközség története ['The History of the "Virgin Mary of the Rock" Parish Church and Congregation']. http://www.kovimaria.hu/index.php?oldal=templom (Accessed: April 10, 2021).

Láng, Orsolya. 2002. "Újabb kutatások a Római Strandfürdő területén" ['Recent Research in the Territory of the Római Open Bath']. Aquincumi Füzetek 8: 54-58.

Póczy, Klára and Hajnóczy Gyula. 1960. Római fürdők Budán ['Roman Baths in Buda']. Budapest: Képzőmüvészeti Alap Kiadóvállalata.

---. 1972. "Aquincum első aqueductusa" ['The First Aqueduct of Aquincum']. Archeológiai Értesitö 99: 15-30.

---. 1980. Közmüvek a római kori Magyarországon ['Public Works in Roman Hungary']. Budapest: Müszaki Könyvkiadó.

---. 1984. "Szent kerületek Aquincum és Brigetio aquaeductusának forráscsoportjánál” [Sacred Sites Near the Sources of the Aqueducts of Aquincum and Brigetio']. Archeológiai Értesitö ['Archaeological Bulletin'] 107: 3-29.

Roman Aqueducts - An Introduction. http://www.romanaqueducts.info/introduction/index.html (Accessed: April 10, 2021).

Virtuvius, Marcus. Ten Books of Architecture. Transl. Morris Hicky Morgan. Annotation of text: David Trumbull, Agathon Associates, 2007. http://www.bostonleadershipbuilders.com/vitruvius/index.htm (Accessed: April 10, 2021). 
Munteán, László. "The Roman Aqueduct of Aquincum in Technological and Cultural Contexts." Hungarian Cultural Studies. e-Journal of the American Hungarian Educators Association, Volume 14 (2021) DOI:

Vladár, Ágnes. 2004. “A Szentendrei út - Záhony utca kereszteződésénél lévő római kori vízvezeték 'pillér csonkok' technikai és müemlékvédelmi mentése" ['Technical and Monument Rescue of the 'Pillar Butts' of the Roman Aqueduct at the Intersection of Szentendrei Road and Záhony Street']. Aquincumi Füzetek 10: 66-71.

Wellner, István. 1973. "Az aquincumi katonaváros nyugat-kelet irányú vízvezetékrendszere" ['The West-East Water Conduit System in Aquincum's Military Town']. Budapest Régiségei 23: 179-181.

Zsidi, Paula. 2002. Aquincum polgárvárosa ['The Civilian Town of Aquincum']. Budapest: Enciklopédia Kiadó. 